\title{
Daily physical activity and related risk factors in COPD
}

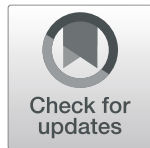

Ali M. Albarrati ${ }^{1} 2^{*}$, Nichola S. Gale ${ }^{1}$, Maggie M. Munnery ${ }^{3}$, John R. Cockcroft ${ }^{3}$ and Dennis J. Shale ${ }^{3}$

\begin{abstract}
Background: Factors associated with reduced daily physical activity (DPA) in patients with COPD are still controversial. Physical inactivity in COPD increases risk of cardiovascular disease, frequent exacerbations, reduced health status, and increased symptoms. We hypothesised that reduced DPA in patients with COPD is independent of traditional risk factors including age and spirometry.

Methods: In this cross-sectional study, DPA (over 7 days) was assessed on 88 community stable patients with COPD and 40 controls free from cardiorespiratory disease. Spirometry, body composition, number of exacerbations, handgrip strength (HGS), modified Medical Research Council (mMRC), arterial stiffness, 6-min walking distance $(6 \mathrm{MWD})$ and BODE index were also determined. Frequent exacerbation was defined as $\geq 2$ and non-frequent exacerbation $<2$.

Results: Patients with COPD had reduced DPA and exercise capacity compared with controls similar in age, BMI and gender, $p<0.001$. Frequent exacerbators had less DPA than infrequent exacerbators and both less than controls, $p<0.001$. Patients with higher BODE index were less active than those with lower index. Time spent on moderate activity was related to cardiovascular risk factors including arterial stiffness. The DPA in patients was independent of age, gender, spirometry, body composition and HGS, $p>0.05$. The level of breathlessness was superior to lung function in predicting the level of DPA.
\end{abstract}

Conclusion: The level of DPA in COPD was independent of traditional risk factors. Breathlessness score is a better predictor of the DPA than lung function and handgrip strength.

Keywords: BODE index, Breathlessness, Daily activity, Exacerbation, Handgrip strength

\section{Background}

Reduced daily physical activity (DPA) is a multifactorial deficit in chronic obstructive pulmonary disease [1]. Reduced DPA is a key contributor to cardiovascular morbidity, recurrent hospital admissions related to exacerbations, disease progression and reduced health related quality of life [2]. Physical inactivity is also the strongest predictor for allcause mortality in this population [3]. Nevertheless, it is

\footnotetext{
* Correspondence: albarrati@ksu.edu.sa

'School of Healthcare Sciences, University Hospital of Wales, Cardiff University, Cardiff, UK

${ }^{2}$ Rehabilitation Sciences Department, College of Applied Medical Sciences, King Saud University, P.O Box 10219, Riyadh 11433, Kingdom of Saudi Arabia Full list of author information is available at the end of the article
}

modifiable and studies indicate that engaging in a regular physical activity could reduce the risk of cardiovascular disease, hospitalisation rate and death related to COPD $[4,5]$. Garcia-Aymerich and colleagues found that participation in physical activity equivalent to walking or cycling for at least $2 \mathrm{~h}$ a week was associated with a $30-40 \%$ reduction in the risk of COPD related hospital admission and mortality [5].

A number of studies have tried to identify factors related to declining of physical activity in COPD and yielded controversial results [6-8]. Most common risk factors reported in these studies are reduced lung function, musculoskeletal strength, breathlessness score and inflammation. The discrepancies in the results may be attributed to the methodological variations as the

(c) The Author(s). 2020 Open Access This article is licensed under a Creative Commons Attribution 4.0 International License, which permits use, sharing, adaptation, distribution and reproduction in any medium or format, as long as you give appropriate credit to the original author(s) and the source, provide a link to the Creative Commons licence, and indicate if changes were made. The images or other third party material in this article are included in the article's Creative Commons licence, unless indicated otherwise in a credit line to the material. If material is not included in the article's Creative Commons licence and your intended use is not permitted by statutory regulation or exceeds the permitted use, you will need to obtain permission directly from the copyright holder. To view a copy of this licence, visit http://creativecommons.org/licenses/by/4.0/ The Creative Commons Public Domain Dedication waiver (http://creativecommons.org/publicdomain/zero/1.0/) applies to the data made available in this article, unless otherwise stated in a credit line to the data. 
patients recruited in these studies were either participating in an inpatient or outpatient rehabilitation program which may not represent typical patients with COPD. Patients with COPD are usually referred to rehabilitation program when they report significant breathlessness and may be physically inactive and deconditioned. This may not reflect the general, less symptomatic COPD population, who may remain active and have a reasonable health status. Moreover, the control subjects recruited in these studies were relatively active and may not be representative of the older population.

Therefore, we hypothesised that decreased DPA in stable community patients with COPD would be independent of traditional risk factors.

\section{Methods}

\section{Subjects}

This is a cross sectional analysis from a large prospective longitudinal study in COPD (The ARCADE study, Clinical Trials No NCT 01656421) [9]. A convenience sample of 93 patients with COPD confirmed with post bronchodilator spirometry and 42 controls, either current or ex-smokers free from respiratory disease were recruited.

All patients were clinically stable and had not had any oral corticosteroids or antibiotics 4 weeks prior to recruitment. Patients were excluded if they were known with inflammatory disease such as rheumatoid arthritis, had oral maintenance corticosteroids and long-term oxygen therapy or had attended pulmonary rehabilitation. Participants were recruited from respiratory outpatient clinics, smoking cessation referrals and general practice databases. Controls were recruited from general practice databases, smoking cessation clinic and patients' relatives. All participants gave written informed consent and the study had approval from the South East Wales Research Ethics Committee.

\section{Anthropometry and body composition measurement}

In all participants, height and weight was measured barefoot with subjects wearing lightweight clothing and body composition was assesed using a single frequency segmental bioelectrical impedance analyser (BC-418 MA, Tanita Corp., Tokyo, Japan). Body mass index (BMI $\mathrm{kg} / \mathrm{m}^{2}$ ), the fat free mass and fat mass were also determined. Waist and hip circumference were measured with a stretch resistant tape [10].

\section{Lung function and COPD related questionnaires}

All participants performed spirometry (Vitalograph alpha, Bucks, UK) to measure the forced expiratory volume in $1 \mathrm{~s}\left(\mathrm{FEV}_{1}\right)$, the forced vital capacity (FVC) and $\mathrm{FEV}_{1} / \mathrm{FVC}$ ratio. Patients were given $400 \mu \mathrm{g}$ of salbutamol via a spacer device and repeated the test $10 \mathrm{~min}$ post bronchodilator. Patients were asked to abstain using their inhalers for at least $6 \mathrm{~h}$ prior to their visit [11] .

Breathlessness was scored using the modified Medical Research Council (MRC) dyspnoea scale. The number of exacerbations in the last year (defined as requirement for antibiotic or oral corticosteroid therapy per year) were recorded. Patients and controls reported also the number of previously diagnosed comorbidities. Infrequent exacerbators were defined as $<2$ in the previous year, while frequent exacerbators as $\geq 2$ [12].

Patients completed the St George's Respiratory Questionnaire (SGRQ) and the COPD assessment test (CAT), both validated measures of health status and symptoms $[13,14]$.

\section{Daily physical activity assessment}

Participants were given a physical activity monitor (SenseWear $^{\text {tm }}$ BodyMedia, Inc. Pittsburgh, PA) on the day of their visit to Wales Heart Research Institute and asked to return the monitor after a week from their visit. The first and last days were excluded from the analysis because of incomplete measurements of the days. Therefore, data from 6 days (4 weekdays plus the weekend) of measurements were available for most participants. Participants were asked to wear the monitor the whole day except during shower or sleep. Wearing time was recorded by the monitor. For a valid day of activity measurement, the threshold was set at $16 \mathrm{~h}$ of monitor's wearing time. Days below that threshold were excluded from analysis. The monitor has been found to be reliable and valid in patients with COPD [15]. To avoid seasonal changes, data were collected from the beginning of May until the end of September. The variables chosen for this analysis were the total daily number of steps (Steps) and daily time spent in at least moderate physical activity as defined by any activity $\geq 3$ METs. Step count was divided to above or below 5000 steps/day as a cut-off value of recommended steps per day [16].

\section{Physical performance}

The 6MWD was performed once according to the American Thoracic Society (ATS) guideline using a 30$\mathrm{m}$ level, straight indoor track [17]. Maximal handgrip strength (HGS) was determined twice in each hand and the mean was calculated for each one using a hand dynamometer (T.K.K. 5401 grip-D, Takei, Japan).

\section{BODE index}

BODE index score was calculated by adding the score of each variable (BMI, post bronchodilator $\mathrm{FEV}_{1}, \mathrm{mMRC}$ and 6MWD). 


\section{Aortic pulse wave velocity}

Peripheral systolic and diastolic BP was measured after 10 min rest in seated and supine positions (OMRON Corporation, Kyoto, Japan). Aortic PWV and central blood pressures including mean arterial pressure (MAP) measured noninvasively using SphygmoCor device (AtCor Medical, Sydney, Australia) [18].

\section{Inflammatory biomarkers}

High sensitivity $\mathrm{C}$ - reactive protein (HsCRP) and fibrinogen were determined by standard assays (Biochemistry, University Hospital of Wales).

\section{Statistical analysis}

All statistical analysis was performed using the statistical software package 23.0 (Chicago, Illinois, U.S.A.). Data were checked for normality prior to analysis. Data were presented as mean and standard deviation or median and interquartile range (IQR). Between groups comparisons were performed using analysis of variance. Categorical data was analysed using the Chi-square test. Correlations between variables were explored using Pearson's and Spearman correlation coefficients. Multivariate analysis was performed using a stepwise multiple regression model. For all analysis $p<0.05$ was considered significant.

\section{Results}

Eighty-eight patients and forty controls had complete data (Fig. 1). Five patients and two controls were removed from the analysis. Two patients and two controls did not wear the monitor for seven days and therefore were excluded. Three patients returned the monitor after 14 days and the batteries of the monitors were dead and we could not retrieve the data after charging the monitors. The patients and controls were similar in age, gender proportion and BMI. The patients had poorer lung function $\left(\mathrm{FEV}_{1}, \mathrm{FVC}\right.$ and their ratio), lower resting oxygen saturations and greater tobacco exposure than the control group (all $p<0.001$ ) (Table 1). The severity of airflow obstruction by GOLD stratification (Table 2). The distribution of the modified MRC breathlessness score was: $\operatorname{mMRC} 0 n=11, \operatorname{mMRC} 1 n=34, \operatorname{mMRC} 2=$ 17, mMRC $3 n=18$ and mMRC $4 n=8$. The patients were also classified according to GOLD quadrants based on CAT score (Table 2).

\section{Measures of daily physical activity}

The DPA was lower in the patients, mean (SD), 4095 (2720) steps than controls 6734 (3491) steps, $p<0.001$, however, there was no difference in DPA for males and females in either group, $p>0.05$. The DPA was not related to age in either patients or controls. Using the minimum recommended level of DPA of 5000 steps/day, only $31 \%$ of the patients had reached the recommended amount of physical activity; while in contrast, $73 \%$ of the controls met the minimum amount of the DPA.

The DPA related to $\mathrm{FEV}_{1} \%$ predicted $(\mathrm{r}=0.39, p<0.001)$, oxygen saturation $\left(r_{s}=0.29, p=0.012\right)$ and mMRC dyspnoea score $(\mathrm{r}=-0.45, p<0.001)$, in the patients. Only was $\mathrm{FEV}_{1} \%$ predicted related to DPA in the controls, $\mathrm{r}=0.39$, $p=0.017$.

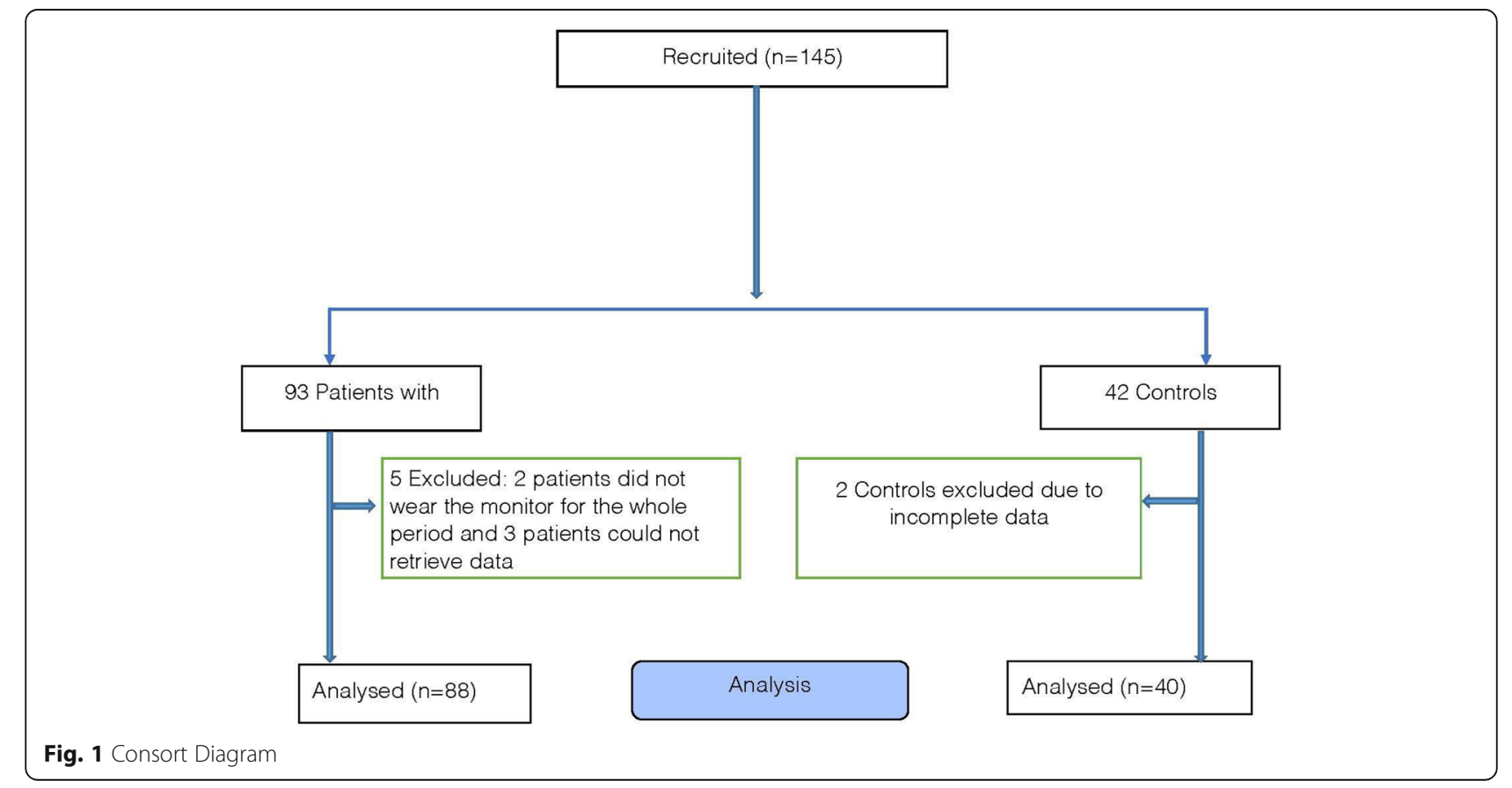


Table 1 Physical and Clinical Characteristics of patients with COPD and Controls

\begin{tabular}{|c|c|c|c|}
\hline & $\operatorname{COPD}(n=88)$ & $\begin{array}{l}\text { Comparator } \\
(n=40)\end{array}$ & $p$ \\
\hline Gender Male: female & $46: 42$ & $19: 21$ & 0.117 \\
\hline Age (years) & $66(8)$ & $66(7)$ & 0.923 \\
\hline Smoking (pack years) & $42.2(24.8)$ & $22.9(20.8)$ & 0.001 \\
\hline $\mathrm{FEV}_{1}(\mathrm{~L})$ & $1.5(0.8)$ & $2.6(0.6)$ & 0.001 \\
\hline $\mathrm{FVC}(\mathrm{L})$ & $2.4(0.9)$ & $3.4(0.9)$ & 0.001 \\
\hline $\mathrm{FEV}_{1} / \mathrm{FVC}$ & $0.52(0.1)$ & $0.78(0.05)$ & 0.001 \\
\hline $\mathrm{FEV}_{1}(\%)$ & $56(17)$ & $106(17)$ & 0.001 \\
\hline FVC (\%) & $84(19)$ & $112(17)$ & 0.001 \\
\hline Resting $\mathrm{O}_{2}$ saturation (\%) & $96(2)$ & $98(1)$ & 0.001 \\
\hline $\mathrm{BMI}\left(\mathrm{kg} / \mathrm{m}^{2}\right)$ & $27.5(5.2)$ & $28.6(4.9)$ & 0.297 \\
\hline Waist:Hip ratio & $0.95(0.09)$ & $0.89(0.06)$ & 0.002 \\
\hline FFM (kg) & $49.5(10.5)$ & $50.9(9.1)$ & 0.486 \\
\hline $\mathrm{FM}(\mathrm{kg})$ & $24.8(9.9)$ & $27.2(10.3)$ & 0.243 \\
\hline FFM/FM & $2.3(1.1)$ & $2.2(1.1)$ & 0.556 \\
\hline FFMI $\left(\mathrm{kg} / \mathrm{m}^{2}\right)$ & $18.2(2.4)$ & $18.5(2.1)$ & 0.589 \\
\hline $\mathrm{FMI}\left(\mathrm{kg} / \mathrm{m}^{2}\right)$ & $9.3(3.9)$ & $10.1(4.3)$ & 0.3 \\
\hline $6 \mathrm{MWD}(\mathrm{m})$ & $336(107)$ & $515(88)$ & 0.001 \\
\hline Mean handgrip (kg) & $27.2(9.6)$ & $29.7(10.2)$ & 0.209 \\
\hline Fibrinogen $(\mathrm{g} / \mathrm{l}) \#$ & $3.8(1.3)$ & $3.2(0.6)$ & 0.012 \\
\hline HsCRP (mg/l)\# & $3.3(3.1)$ & $1.6(3.2)$ & 0.023 \\
\hline No. Steps & $4095(2720)$ & 6734 (3491) & 0.001 \\
\hline $\begin{array}{l}\text { Time spent on moderate } \\
\text { activity (hr)* }\end{array}$ & $1.3(0.5-2.2)$ & $1.3(0.7-2.1)$ & 0.662 \\
\hline No. Comorbidity & $1.3(1.2)$ & $0.8(0.8)$ & 0.027 \\
\hline
\end{tabular}

\section{Daily physical activity and disease severity}

Level of DPA differed across the GOLD categories, between GOLD 1 and GOLD 4, $p=0.004$ (Fig. 2). Patients with an $\mathrm{FEV}_{1}>50 \%$ had greater level of DPA, lower exacerbation rate, breathlessness score and CAT score than patients with an $\mathrm{FEV}_{1}<50 \%, p<0.001$. There was an association between level of DPA and BODE index, $p<0.001$.

Table 2 Distribution of Patients with COPD according to GOLD classifications and Quadrants

\begin{tabular}{llll}
\hline GOLD Classification & Patients Number & GOLD Quadrants & $\begin{array}{l}\text { Patients } \\
\text { Number }\end{array}$ \\
\hline GOLD I & 9 & GOLD A & 8 \\
GOLD II & 50 & GOLD B & 24 \\
GOLD III & 25 & GOLD C & 10 \\
GOLD IV & 4 & GOLD D & 46 \\
\hline
\end{tabular}

Patients with BODE score of $\geq 6$ walked less significantly than patients with a lower score, $p<0.001$ (Fig. 3).

\section{Daily physical activity and body composition and physical} function

There was no relationship between body composition parameters and DPA in the patients or control group. However, in the patients, the time spent undertaking moderate activity was related to BMI, $\mathrm{r}=-0.39$, FM, $\mathrm{r}=$ -0.37 , FFM:FM, $\mathrm{r}=0.50$, all $p<0.001$. Similar relationships were evident in the control group, all $p<0.05$.

The 6MWD and HGS were less in patients than controls, both $p<0.001$ (Table 1 ). In the patients, the level of daily of daily physical activity was related to the 6MWD, $\mathrm{r}=0.45, p=0.001$, and controls, $\mathrm{r}=0.49, p=$ 0.002 , but it was not related to HGS, $p>0.05$. The 6MWD and HGS were all related to each other in the patients, $p<0.01$.

\section{Daily physical activity and aortic stiffness}

In the patients, the time spent undertaking moderate activity was related to aortic stiffness ( $r s=-0.28, p<0.01)$, resting oxygen saturation $(r s=-0.38, p<0.002)$. This was not evident in controls. Aortic stiffness was greater in patients, $9.5(2.2)$, than controls, $8.2(1.4), p<0.01$.

\section{Patient reported outcomes}

The level of DPA and the SGRQ total score were related $(\mathrm{r}=-0.38, p<0.001)$, as was the SGRQ activity domain $(\mathrm{r}=-0.40, p<0.001)$. The CAT score was also related to the level DPA $(r=-0.34, p=0.003)$. The 6MWD also related to the total SGRQ score, $r=-0.63$, and the CAT score $\mathrm{r}=-0.54$, (all $p<0.001)$.

Of the patients, 41 reported $0-1$ exacerbations/ year and 47 reported two or more exacerbations/ year. The level of DPA was related to the frequency of exacerbations $\mathrm{r}=-0.34, p<0.001$, and frequent exacerbators, 3348 (2221) steps, had lower physical activity of daily living than infrequent exacerbators, 5094 (3027) steps.

\section{Systemic inflammation}

Circulating CRP and fibrinogen were greater in patients than controls $(p<0.001)$ and both were related to the level of DPA, CRP, $r_{s}=-0.29, p=0.013$, and fibrinogen, $\mathrm{r}=-0.30, p=0.009$, but were unrelated to the level of DPA in the control group.

\section{Predictive factors for the daily physical activity}

In the patients, a stepwise multivariate regression analysis including DPA as a dependent variable and $\mathrm{FEV}_{1} \%$, mMRC and the number of exacerbations as the independent variables showed that mMRC and number of exacerbations explained $28 \%$ of the variability in the DPA with $\mathrm{FEV}_{1} \%$ predicted excluded from the analysis, 


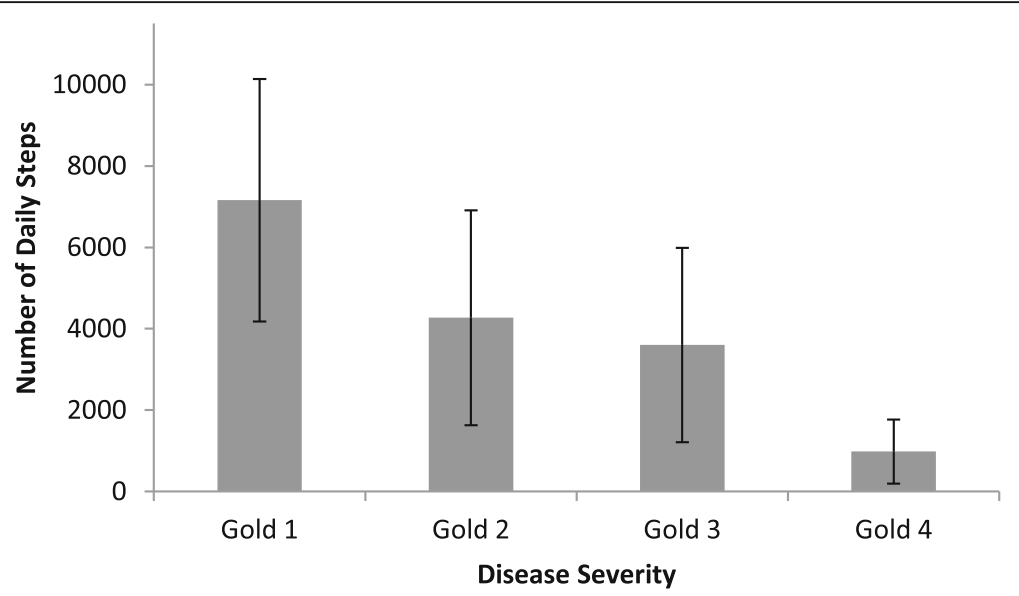

Fig. 2 Daily physical activity disease severity (GOLD categories). Bars represent means and vertical lines represent upper and lower 95\% confidence intervals for each category

adjusted $\mathrm{R}^{2}=0.28, p<0.001$. The mMRC and the number of exacerbations explained 34 and $25 \%$ of the reduction in the DPA, respectively.

\section{Discussion}

To our knowledge, this is the first study to comprehensively examine risk factors associated with daily physical activity in stable community patients with COPD and controls similar in age and gender. The DPA in COPD was associated with level of breathlessness and frequency of exacerbations, independent of age, lung function, sex, peripheral muscle mass strength.

The GOLD classification was not discriminative enough between patients with moderate and severe impaired DPA. The level of breathlessness was found to be superior to lung function. This may be explained as a number of studies have found that $F E V_{1}$ is less sensitive to describe the complexity of COPD and weakly related to the level of breathlessness $[19,20]$. Breathlessness is the most common reason for visiting primary care and respiratory physicians regardless the severity of lung function [21]. A recent study on patients attending primary care found physical inactivity was associated with breathlessness independent of lung function [22]. Perception of breathlessness, which patients experience during performing DPA, is involved in a complex mechanism beyond respiratory mechanical factors [23]. Patients with severe breathlessness often limit their DPA to minimise dyspnoea and creating a vicious cycle of inactivity, muscle atrophy, deconditioning and which result in greater activity intolerance [15, 24-27]. Similar findings reported by other researchers confirming the independent relationship between disease severity and DPA [8, 28].

Patients with poor prognosis (BODE $\geq 6$ ) had limited DPA which is a strong predictor of poor outcomes

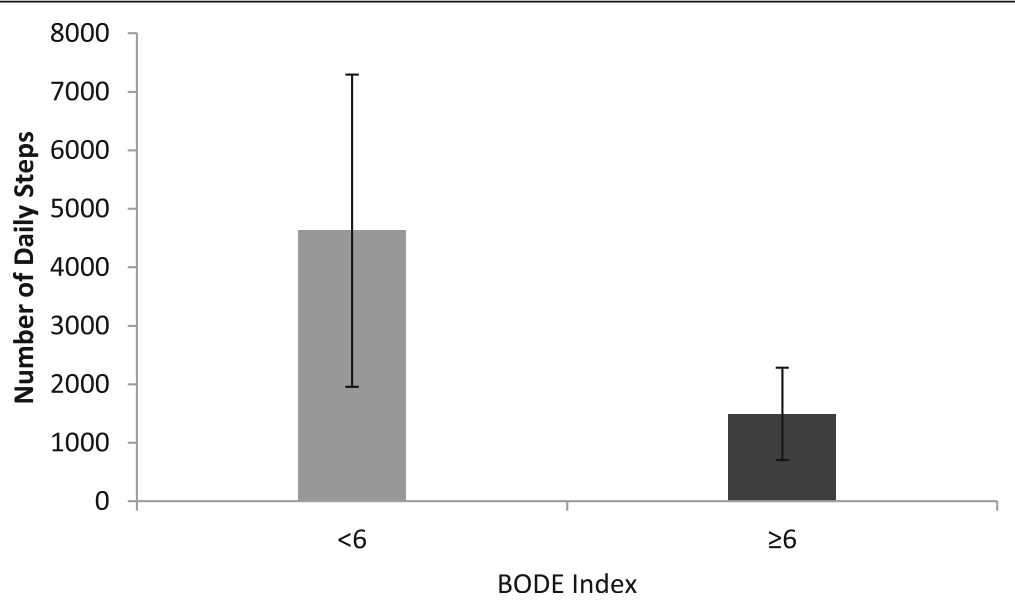

Fig. 3 Daily Physical activity and BODE index<Or $>6$. Bars represent means and vertical lines represent upper and lower 95\% confidence intervals for each category 
including mortality $[29,30]$. Similarly, a number of studies reported in a small cohort study in patients with COPD a direct relationship between physical inactivity and increased BODE index [24, 31]. This is supported by the concept that reduced DPA is a strong predictor of morbidity and mortality in patients with COPD $[3,5]$. Pitta and colleagues found inactivity for just one day doubled the BODE score, which increased the probability of premature mortality [24]. BODE index is a multidimensional and appears to have the capacity to stratify patients better than a single marker of airway severity, as $\mathrm{FEV}_{1}$ cannot reflects the whole picture of COPD.

Reduced DPA increases the risk of cardiovascular disease and its related risk factors including arterial stiffness. Arterial stiffness is a validated marker of $\mathrm{CV}$ morbidity and mortality. A few studies have examined the relationship between DPA and arterial stiffness in COPD and showed different results [32, 33]. In our study, moderate DPA was associated with reduced arterial stiffness. Increased arterial stiffness is a surrogate marker of increased risk of cardiovascular disease in COPD, which could be reduced by increasing DPA [3437]. Indeed, a number of studies found a reduction in aortic stiffness after patients with COPD attended a structured programme of pulmonary rehabilitation [37, 38]. A recent study found that patients engaging in any type of moderate physical activity was associated with lower mortality rate after one year compared to inactive patients [39].

Altered body composition is an accepted feature of COPD with several studies reporting reduced musculoskeletal mass and strength [40-43]. However, in our study, neither muscle mass nor HGS was associated with reduced DPA and exercise capacity. Van Gestel and colleagues reported a similar finding to our study and showed that HGS was not associated with DPA and could not be used to predict DPA [44]. A possible explanation is that despite the limitations of lower limb activities by breathlessness, upper limb activities and strength may be maintained [1].

In addition, the larger lower limb mass may be more affected by circulating inflammation, a key feature of COPD. Increased circulatory inflammation may profoundly alter musculoskeletal function, increase muscle oxidative stress and accelerate muscle protein degradation $[21,45]$. Systemic inflammation (CRP) was elevated in COPD in the present study and was associated with fat mass a potential source of inflammation and impaired DPA. Increased inflammatory biomarkers i.e. CRP and fibrinogen, which are associated with increased risk of cardiovascular disease and insulin resistance, and their association with reduced DPA has been previously shown in individuals with COPD and community dwellers $[46,47]$. Increased systemic inflammation (SI) is linked to an exacerbation frequency, which is associated with breathlessness and impaired DPA [46].

\section{Limitations}

A key limitation of this study is its cross-sectional nature, and this issue is being addressed in the ongoing longitudinal ARCADE study. We had a limited number of DPA monitors so which curtailed recruitment.

\section{Conclusion}

The increased level of breathlessness and frequency of exacerbation are key factors in limiting daily physical activity in patients with COPD independent of loss of muscle mass and strength. The association between reduced DPA and breathlessness suggests that interventions to improve perception of breathlessness may optimise patient outcomes including physical activity. There is a need for long-term behavioural interventions to increase/maintain DPA in patients with COPD.

\section{Abbreviations}

6MWD: Six minute walk distance; BMI: Body mass index; DPA: Daily physical activity; FEV1: Forced expiratory volume in $1 \mathrm{~s}$; FFM: Fat free mass; FFMI: Fat free mass index; FM: Fat mass; FMI: Fat mass index; FVC: Forced vital capacity; HGS: Handgrip strength; HsCRP: High sensitivity C- reactive protein;

SI: Systemic inflammation

\section{Acknowledgements}

The authors would like to thank primary and secondary care physicians as well as the British Lung foundation for assistance with recruitment.

\section{Authors' contributions}

$N G, J C$ and DS designed the study. AA and MM performed the study and collected data. AA, NG analyzed the data. AA, NG, DS wrote the paper. All authors critically reviewed the paper and approved it.

Funding

The ARCADE study was funded by GSK.

\section{Availability of data and materials}

The datasets generated and/or analysed during the current study are not publicly available due other manuscripts will be published from this data, but are available from the corresponding author on reasonable request.

Ethics approval and consent to participate

All subjects gave written informed consent and the study had approval from the South East Wales Research Ethics Committee, part of the National Research Ethics Service (UK). The ARCADE study, Clinical Trials No NCT 01656421).

\section{Consent for publication}

Not applicable.

\section{Competing interests}

The authors declare no conflict of interest.

\section{Author details}

${ }^{1}$ School of Healthcare Sciences, University Hospital of Wales, Cardiff University, Cardiff, UK. ${ }^{2}$ Rehabilitation Sciences Department, College of Applied Medical Sciences, King Saud University, P.O Box 10219, Riyadh 11433, Kingdom of Saudi Arabia. ${ }^{3}$ Cardio-Respiratory Medicine, Wales Heart Research Institute, Cardiff University, University Hospital of Wales, Heath Park Campus, Cardiff CF14 4XN, UK. 


\section{Received: 25 October 2019 Accepted: 19 February 2020} Published online: 05 March 2020

\section{References}

1. Maltais F, Decramer M, Casaburi R, Barreiro E, Burelle $Y$, Debigaré $R$, et al. An official American Thoracic Society/European Respiratory Society statement: update on limb muscle dysfunction in chronic obstructive pulmonary disease. Am J Respir Crit Care Med. 2014;189(9):e15-62.

2. Vestbo J, Hurd SS, Agusti AG, Jones PW, Vogelmeier C, Anzueto A, et al. Global Strategy for the Diagnosis, Management and Prevention of Chronic Obstructive Pulmonary Disease, GOLD Executive Summary. Am J Respir Crit Care Med. 2013;187(4):346-65.

3. Waschki B, Kirsten A, Holz O, Muller KC, Meyer T, Watz H, et al. Physical activity is the strongest predictor of all-cause mortality in patients with COPD: a prospective cohort study. Chest. 2011;140(2):331-42.

4. Blair SN, Cheng Y, Holder JS. Is physical activity or physical fitness more important in defining health benefits? Med Sci Sports Exerc. 2001;33(6 Suppl):S379-99 discussion S419-20.

5. Garcia-Aymerich J, Lange P, Benet M, Schnohr P, Anto JM. Regular physical activity reduces hospital admission and mortality in chronic obstructive pulmonary disease: a population based cohort study. Thorax. 2006;61(9): 772-8.

6. Singh S, Morgan MD. Activity monitors can detect brisk walking in patients with chronic obstructive pulmonary disease. J Cardpulm Rehabil. 2001;21(3): 143-8.

7. Coronado M, Janssens JP, de Muralt B, Terrier P, Schutz Y, Fitting JW. Walking activity measured by accelerometry during respiratory rehabilitation. J Cardpulm Rehabil. 2003;23(5):357-64.

8. Jehn ML, Schmidt-Trucksass A. Association between daily activity and VO2peak. Med Sci Sports Exerc. 2010;42(6):1229 author reply 30.

9. Gale NS, Albarrati AM, Munnery MM, Munnery IC, Irfan M, Bolton CE, et al. Assessment of risk in chronic airways disease evaluation (ARCADE): protocol and preliminary data. Chron Respir Dis. 2014;11(4):199-207.

10. WHO. Waist Circumference and Waist-Hip Ratio: Report of a WHO Expert Consultation 2008 [Available from: http://www.who.int/nutrition/ publications/obesity/WHO_report_waistcircumference_and_waisthip_ratio/ en/index.html.

11. Global Initiative for Chronic Obstructive Lung Disease G. Global Strategy for the Diagnosis, Management and Prevention of COPD, Global Initiative for Chronic Obstructive Lung Disease (GOLD). [Internet]. 2015. Available from: http://www.goldcopd.org.

12. Rabe KF, Hurd S, Anzueto A, Barnes PJ, Buist SA, Calverley P, et al. Global strategy for the diagnosis, management, and prevention of chronic obstructive pulmonary disease: GOLD executive summary. Am J Respir Crit Care Med. 2007;176(6):532-55.

13. Jones PW, Harding G, Berry P, Wiklund I, Chen WH, Kline LN. Development and first validation of the COPD assessment test. Eur Respir J. 2009;34(3): 648-54

14. Jones PW, Quirk FH, Baveystock CM, Littlejohns P. A self-complete measure of health status for chronic airflow limitation. The St. George's respiratory questionnaire. Am Rev Respir Dis. 1992;145(6):1321-7.

15. Pitta F, Troosters T, Probst VS, Spruit MA, Decramer M, Gosselink R Quantifying physical activity in daily life with questionnaires and motion sensors in COPD. Eur Respir J. 2006;27(5):1040-55.

16. Martin SB, Morrow JR Jr, Jackson AW, Dunn AL. Variables related to meeting the CDC/ACSM physical activity guidelines. Med Sci Sports Exerc. 2000; 32(12):2087-92.

17. ATS statement: quidelines for the six-minute walk test. Am J Respir Crit Care Med. 2002;166(1):111-7.

18. Laurent S, Cockcroft J, Van Bortel L, Boutouyrie P, Giannattasio C, Hayoz D, et al. Expert consensus document on arterial stiffness: methodological issues and clinical applications. Eur Heart J. 2006;27(21):2588-605.

19. Cote CG, Celli BR. BODE index: a new tool to stage and monitor progression of chronic obstructive pulmonary disease. Pneumonol Alergol Pol. 2009; 77(3):305-13.

20. Cote CG, Dordelly LJ, Celli BR. Impact of COPD exacerbations on patient centered outcomes. Chest. 2007:131(3):696-704.

21. O'Donnell DE, Ora J, Webb KA, Laveneziana P, Jensen D. Mechanisms of activity-related dyspnea in pulmonary diseases. Respir Physiol Neurobiol. 2009;167(1):116-32.
22. Kelly JL, Elkin SL, Fluxman J, Polkey MI, Soljak MA, Hopkinson NS. Breathlessness and skeletal muscle weakness in patients undergoing lung health screening in primary care. COPD. 2013;10(1):40-54.

23. Gifford AH, Mahler DA, Waterman LA, Ward J, Kraemer WJ, Kupchak BR, et al. Neuromodulatory effect of endogenous opioids on the intensity and unpleasantness of breathlessness during resistive load breathing in COPD. COPD. 2011;8(3):160-6.

24. Pitta F, Troosters T, Probst VS, Lucas S, Decramer M, Gosselink R. Potential consequences for stable chronic obstructive pulmonary disease patients who do not get the recommended minimum daily amount of physical activity. J Bras Pneumol. 2006:32(4):301-8.

25. Seymour JM, Ward K, Sidhu PS, Puthucheary Z, Steier J, Jolley CJ, et al. Ultrasound measurement of rectus femoris cross-sectional area and the relationship with quadriceps strength in COPD. Thorax. 2009;64(5):418-23.

26. Singer J, Yelin EH, Katz PP, Sanchez G, Iribarren C, Eisner MD, et al. Respiratory and skeletal muscle strength in chronic obstructive pulmonary disease: impact on exercise capacity and lower extremity function. J Cardiopulm Rehabil Prev. 2011;31(2):111-9.

27. Wagner PD. Skeletal muscles in chronic obstructive pulmonary disease: deconditioning, or myopathy? Respirology. 2006;11(6):681-6.

28. Troosters T, Sciurba F, Battaglia S, Langer D, Valluri SR, Martino L, et al. Physical inactivity in patients with COPD, a controlled multi-center pilotstudy. Respir Med. 2010;104(7):1005-11.

29. Waschki B, Kirsten AM, Holz O, Mueller KC, Schaper M, Sack AL, et al. Disease progression and changes in physical activity in patients with chronic obstructive pulmonary disease. Am J Respir Crit Care Med. 2015;192(3):295-306.

30. Celli BR, Cote CG, Marin JM, Casanova C, Montes de Oca M, Mendez RA, et al. The body-mass index, airflow obstruction, dyspnea, and exercise capacity index in chronic obstructive pulmonary disease. N Engl J Med. 2004;350(10):1005-12.

31. Moy ML, Matthess K, Stolzmann K, Reilly J, Garshick E. Free-living physical activity in COPD: assessment with accelerometer and activity checklist. J Rehabil Res Dev. 2009;46(2):277-86

32. Sievi NA, Franzen D, Kohler M, Clarenbach CF. Physical inactivity and arterial stiffness in COPD. Int J Chron Obstruct Pulmon Dis. 2015;10:1891-7.

33. Stickland MK, Vogan N, Petersen SR, Wong EY, Bhutani M. Physical activity and arterial stiffness in chronic obstructive pulmonary disease. Respir Physio Neurobiol. 2013;189(1):188-94.

34. Watz $H$, Waschki B, Boehme C, Claussen M, Meyer T, Magnussen $H$. Extrapulmonary effects of chronic obstructive pulmonary disease on physical activity: a cross-sectional study. Am J Respir Crit Care Med. 2008; 177(7):743-51.

35. Sabit R, Bolton CE, Edwards PH, Pettit RJ, Evans WD, McEniery CM, et al. Arterial stiffness and osteoporosis in chronic obstructive pulmonary disease. Am J Respir Crit Care Med. 2007:175(12):1259-65.

36. Macnee W, Maclay J, McAllister D. Cardiovascular injury and repair in chronic obstructive pulmonary disease. Proc Am Thorac Soc. 2008:5(8):824-33.

37. Gale NS, Duckers JM, Enright S, Cockcroft JR, Shale DJ, Bolton CE. Does pulmonary rehabilitation address cardiovascular risk factors in patients with COPD? BMC Pulmon Med. 2011;11:20

38. Vanfleteren LE, Spruit MA, Groenen MT, Bruijnzeel PL, Taib Z, Rutten EP, et al. Arterial stiffness in patients with COPD: the role of systemic inflammation and the effects of pulmonary rehabilitation. Eur Respir J. 2014; 43(5):1306-15

39. Moy ML, Gould MK, Liu I-LA, Lee JS, Nguyen HQ. Physical activity assessed in routine care predicts mortality after a COPD hospitalisation. ERJ Open Res. 2016;2(1):00062-2015.

40. Agusti A. Physical activity and chronic obstructive pulmonary disease. Am J Respir Crit Care Med. 2008;177(7):675-6.

41. Ansari K, Keaney N, Taylor I, Burns G, Farrow M. Muscle weakness, health status and frequency of exacerbations in chronic obstructive pulmonary disease. Postgrad Med J. 2012;88(1041):372-6.

42. Cesari M, Pedone C, Chiurco D, Cortese L, Conte ME, Scarlata S, et al. Physical performance, sarcopenia and respiratory function in older patients with chronic obstructive pulmonary disease. Age Ageing. 2012;41(2):237-41.

43. Eliason G, Abdel-Halim S, Arvidsson B, Kadi F, Piehl-Aulin K. Physical performance and muscular characteristics in different stages of COPD. Scand J Med Sci Sports. 2009:19(6):865-70.

44. van Gestel AJ, Clarenbach CF, Stowhas AC, Rossi VA, Sievi NA, Camen G, et al. Predicting daily physical activity in patients with chronic obstructive pulmonary disease. PLoS One. 2012;7(11):e48081. 
45. Reid WD, Rurak J, Harris RL. Skeletal muscle response to inflammation-lessons for chronic obstructive pulmonary disease. Crit Care Med. 2009; 37(10 Suppl):S372-83.

46. Watz H, Waschki B, Meyer T, Magnussen $\mathrm{H}$. Physical activity in patients with COPD. Eur Respir J. 2009;33(2):262-72.

47. Geffken DF, Cushman M, Burke GL, Polak JF, Sakkinen PA, Tracy RP. Association between physical activity and markers of inflammation in a healthy elderly population. Am J Epidemiol. 2001;153(3):242-50

\section{Publisher's Note}

Springer Nature remains neutral with regard to jurisdictional claims in published maps and institutional affiliations.

Ready to submit your research? Choose BMC and benefit from:

- fast, convenient online submission

- thorough peer review by experienced researchers in your field

- rapid publication on acceptance

- support for research data, including large and complex data types

- gold Open Access which fosters wider collaboration and increased citations

- maximum visibility for your research: over $100 \mathrm{M}$ website views per year

At BMC, research is always in progress.

Learn more biomedcentral.com/submissions 